\title{
Robot Inverted Pendulum Beroda Dua (IPBD) dengan Kendali Linear Quadratic Regulator (LQR)
}

\author{
FAHMIZAL ${ }^{1}$, MUHAMMAD ARROFIQ ${ }^{2}$, RONALD ADRIAN ${ }^{3}$, AFRIZAL MAYUB $^{4}$ \\ 1,2,3Departemen Teknik Elektro dan Informatika, Sekolah Vokasi Universitas Gadjah \\ Mada \\ ${ }^{4}$ Pascasarjana S2 Pendidikan IPA FKIP, Universitas Bengkulu \\ Email: fahmizal@ugm.ac.id
}

Received 3 Januari 2019 | Revised 3 Februari 2019 | Accepted 24 Maret 2019

\begin{abstract}
ABSTRAK
Makalah ini memaparkan proses pemodelan robot inverted pendulum beroda dua (IPBD) menggunakan dinamika Lagrange. Setelah sistem model robot IPBD diperoleh, teknik kendali optimal dalam hal ini menggunakan linear quadratic regulator (LQR) digunakan untuk melihat step respon sistem dan tanggapan respon sistem terhadap gangguan. Sebelum kendali $L Q R$ diimplementasikan, simulasi menggunakan Simulink Matlab dilakukan untuk mendapat parameter gain $K$ pada kendali LQR. Selanjutnya, dengan mengubah-ubah matriks pembobot $Q$ akan diperoleh variasi gain $K$. Pada penelitian ini dilakukan variasi matriks pembobotan $Q$ sebanyak lima jenis. Sedangkan matriks elemen $R$ dituning dengan nilai satu. Dari hasil pengujian diperoleh bahwa dengan membesarkan pembobotan matriks $Q$, dihasilkan respon menuju keadaan steady lebih cepat dan overshoot berkurang. Parameter gain $K$ dari hasil simulasi selanjutnya akan diimplementasikan secara embedded programming ke dalam Arduino Uno pada sistem robot IPBD.
\end{abstract}

Kata kunci: Inverted pendulum beroda, Pemodelan, $L Q R$

\begin{abstract}
This paper describes the process of modeling two-wheeled pendulum inverted robots (IPBD) using the Lagrange dynamics. After the IPBD robot model system was obtained, the optimal control technique in this case using a linear quadratic regulator $(L Q R)$ was used to see the system response step and the response of the system response to interference. Before the $L Q R$ control is implemented, simulation using Matlab Simulink is conducted to get the gain $K$ parameter on the $L Q R$ control. Furthermore, by varying the weighting matrix $Q$, the gain variation $K$ will be obtained. There are five types of $Q$ weighting matrix in this research and the $R$ element matric is tuned with a value of 1 . From the test, obtained results show that by raising the weighting matrix $Q$ is produced a faster response to the steady state and overshoot is reduced. At the final stage, the gain $K$ parameter from the simulation results will be implemented by embedded programming into Arduino Uno on the IPBD robot system.
\end{abstract}

Keywords: Wheeled inverted pendulum, Modelling, $L Q R$ 


\section{PENDAHULUAN}

Robotika adalah bidang yang sangat menarik di bidang rekayasa maupun pengetahuan. Bidang ini telah memberikan kontribusi yang penting dalam dunia industri, dan telah banyak industri yang menggunakan robot untuk berbagai tugas seperti assembling, pengelasan, pengecatan dan pemindahan material. Secara paralel, kita menyaksikan munculnya robot yang memiliki peran penunjang (assistive) (Fasola, 2013) seperti robot pencari korban, penyapu ranjau, pengawasan (surveillance) (Song, 2009), eksplorasi (Nagatani, 2011), dan keamanan (Kim, 2010).

Di samping itu, minat penelitian ke arah robot dengan kemampuan merayap (climbing) (Zhang, 2006), berjalan tegak (walking) (Kuo, 2016), dan kesetimbangan (balancing) (Mayub, 2018) juga mendapat perhatian lebih. Pembahasan khusus dalam hal dinamik robot juga sangat menjanjikan dari segi kontribusi keilmuan. Perbedaan yang mendasar dari dinamika robot dan kinematika robot adalah penguraian gaya-gaya yang bekerja. Dinamika robot merupakan pergerakan robot dengan memperhatikan gaya-gaya yang bekerja, sedangkan kinematika tidak memperhatikan hal-hal tersebut. Tujuan utama kajian dinamik ini adalah untuk mendapatkan desain kendali yang kokoh (robust) yang mampu meredam gangguan dengan baik. Masih banyak struktur robot yang kompleks belum dikaji secara mendalam model dinamik oleh karena rumitnya persoalan pemodelan matematik sistem robot, sifat fisik alami (friksi pada poros aktuator, backlash pada gearbox, noise pada sensor, ketidaklinieran aktuator, dsb.) dan lingkungan (gangguan luar berupa efek pembebanan, jalan yang tidak rata, getaran, dll.). Kendali dasar dapat dirancang secara sistematis dari persamaan dinamik ini. Pada artikel ini sistem dinamik dari robot Inverted Pendulum Beroda Dua (IPBD) diturunkan menggunakan dinamika Lagrange.

Robot IPBD mengadopsi model sistem dari inverted pendulum konvensional dengan konfigurasi sistem fisik terdiri dari bandul, pedati dan motor DC. Penerapan sistem kendali pada robot IPBD juga beragam mulai dari kendali linear seperti PID (Pratama, 2015), kendali cerdas seperti Fuzzy (Bobby, 2015; Fahmizal, 2017) dan kendali non-linear seperti Sliding Mode Controller (SMC) (Huang, 2010). Robot IPBD bersifat non-linear dan merupakan sistem yang tidak stabil. Robot IPBD pada artikel ini menggunakan motor DC sebagai penggerak. Motor DC yang terletak pada masing-masing roda kiri dan kanan akan memberikan variabel gaya untuk mempertahankan kestabilan robot. Pada artikel ini akan dipaparkan kendali optimal Linear Quadratic Regulator (LQR) yang dapat menjaga keseimbangan dari robot. Pada perancangan robot ini, sensor kemiringan dan sensor jarak digunakan sebagai masukan kondisi state dari robot. Sensor kemiringan yang diterapkan pada robot IPBD menggunakan Inertia Measurement Unit (IMU) MPU 6050 dan sensor ultasonik sebagai sensor pendeteksi jarak posisi.

Pada artikel ini, model matematis robot IPBD diturunkan dari hubungan fisis sistem. Model tersebut harus dapat menggambarkan karakteristik dinamis sistem secara memadai. Model dari robot ini diturunkan menggunakan dinamika Lagrange yang selanjutnya disimulasikan menggunakan Simulink Matlab. Fungsi sinyal step digunakan untuk melihat respon sistem pada kalang terbuka. Lebih jauh, sistem kendali pada kalang tertutup (close loop) menggunakan LQR. LQR merupakan metode kendali optimum dengan tujuan utama membawa state akhir ke titik nol dengan meminimalkan cost function. Jenis kendali ini bertujuan mencari nilai gain state feedback (K).

Artikel ini disusun menjadi lima bagian. Pada bagian 2, metodologi dalam penelitian ini diusulkan. Di bagian 3 simulasi model robot IPBD dengan menggunakan LQR dijelaskan. Prosedur implemenentasi kendali LQR disajikan di bagian 4 beserta eksperimen yang 
menunjukkan keefektifan dan manfaat metode yang diusulkan. Bagian 5 merupakan kesimpulan dari penelitian ini.

\section{METODOLOGI}

\subsection{Pemodelan Robot Inverted Pendulum Beroda}

Model matematis diturunkan dari hubungan fisis sistem. Model tersebut harus dapat menggambarkan karakteristik dinamis sistem secara memadai. Model teoritis yang lengkap dari sistem robot IPBD dapat diturunkan menggunakan dinamika Lagrange. Langkah pertama adalah penentuan koordinat sistem, kemudian penentuan gaya, fungsi energi dan Lagrangian. Selanjutnya menggunakan persamaan Lagrange untuk menentukan persamaan gerak sistem. Diagram skematik dinamika IPBD dapat dilihat pada Gambar 1 dan sistem koordinat ini akan digunakan untuk selanjutnya dianalisis.

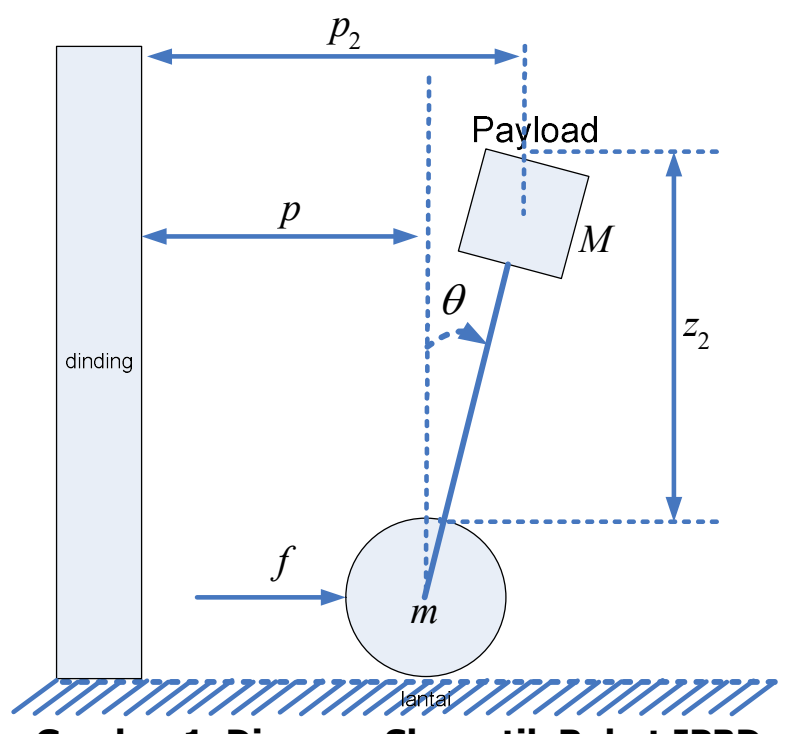

Gambar 1. Diagram Skematik Robot IPBD

Analisis fisis dinamika robot IPBD adalah sebagai berikut:

1. Sistem koordinat umum

Sistem robot IPBD ini adalah sistem yang memiliki dua buah kebebasan sehingga sistem ini dapat dipresentasikan menggunakan dua koordinat umum. Pada analisis kali ini, koordinat yang dipilih adalah pergeseran secara horizontal dari robot $p$, dan pergeseran sudut dari bandul theta $(\theta)$. $p$ bernilai positif ke arah kanan dan $\theta$ bernilai positif searah jarum jam, dihitung dari posisi terbaliknya.

2. Energi kinetik dan energi potensial

Energi kinetik untuk roda $\left(E_{R}\right)$ terdiri dari energi kinetik rotasi roda dan translasi roda yang dijelaskan pada Persamaan (1), dengan $m$ adalah massa roda dan $\dot{p}$ adalah kecepatan robot kearah horizontal.

$$
\begin{aligned}
& E_{R}=E_{\text {rotasi }}+E_{\text {translasi }} \\
& E_{R}=\frac{1}{2} I \omega^{2}+\frac{1}{2} m \dot{p}^{2} \\
& E_{R}=\frac{1}{2}\left(\frac{1}{2} m R^{2}\right) \frac{\dot{p}^{2}}{R^{2}}+\frac{1}{2} m \dot{p}^{2}=\frac{3}{4} m \dot{p}^{2}
\end{aligned}
$$


Energi kinetik untuk bandul $\left(E_{B}\right)$ dapat dinyatakan pada Persamaan (2), dengan $M$ adalah massa bandul. Berdasarkan Gambar 1 , nilai $v$ dapat direpresentasikan menjadi bentuk $\dot{p}_{2}^{2}+\dot{z}_{2}^{2}$, dengan turunan dari $p_{2}$ dan $z_{2}$ dijelaskan pada Persamaan (3) dan Persamaan (4).

$$
\begin{gathered}
E_{B}=\frac{1}{2} M v^{2} \\
p_{2}=p+l \sin \theta \text { maka } \dot{p}_{2}=\dot{p}+l \dot{\theta} \cos \theta \\
z_{2}=l \cos \theta \text { maka } \dot{z}_{2}=-l \dot{\theta} \sin \theta
\end{gathered}
$$

Maka dapat diperoleh Persamaan (5) yang merupakan jabaran dari Persamaan (2).

$$
\begin{aligned}
& E_{B}=\frac{1}{2} M\left(\dot{p}_{2}+\dot{z}_{2}\right)^{2} \\
& E_{B}=\frac{1}{2} M\left(\dot{p}_{2}^{2}+2 \dot{p} \dot{\theta} l \cos \theta+\frac{1}{2} M l^{2} \dot{\theta}^{2}\right)
\end{aligned}
$$

Sehingga total energi kinetik $T$ adalah $E_{R}$ dijumlahkan dengan $E_{B}$ atau jika dalam persamaan dinyatakan dalam Persamaan (6).

$$
T=\frac{3}{4} m \dot{p}^{2}+\frac{1}{2} m \dot{p}^{2}+M l \cos \theta \dot{p} \dot{\theta}+\frac{1}{2} M l^{2} \dot{\theta}^{2}
$$

Karena robot hanya bergerak pada sumbu horizontal saja, maka energi potensial $V$ dari sistem hanya ditentukan sepenuhnya oleh sudut dari bandul seperti yang dijelaskan pada Persamaan (7), dengan $g$ adalah percepatan gravitasi bumi dan /adalah panjang bandul.

$$
V=M g l \cos \theta
$$

3. Lagrangian

Ditahap ini, dilakukan analisis dinamik sistem dengan menggunakan metode Lagrangian yang dijelaskan pada Persamaan (8).

$$
L=T-V
$$

Dengan mensubtitusi Persamaan (6) dan Persamaan (7) ke Persamaan (8) maka diperoleh Lagrangian-nya menjadi seperti yang dijelaskan pada Persamaan (9).

$$
L=\left(\frac{3}{4} m+\frac{1}{2} m\right) \dot{p}^{2}+M l \cos \theta \dot{p} \dot{\theta}+\frac{1}{2} M l^{2} \dot{\theta}^{2}-M g l \cos \theta
$$

4. Persamaan Lagrange

Koordinat umum yang dipilih pada Persamaan (9) adalah $(p, \theta)$. Dari koordinat umum tersebut diterapkan analisis Lagrange lainnya yaitu masing-masing untuk $p$ dan $\theta$. Untuk menyelesaikan $p$ dengan persamaan Lagrange dijelaskan pada Persamaan (10).

$$
\frac{d}{d t}\left(\frac{\partial L}{\partial \dot{p}}\right)-\frac{\partial L}{\partial p}=f
$$

Menggunakan Persamaan (9) untuk mengevaluasi turunan parsial pada Persamaan (10) maka menghasilkan Persamaan (11).

$$
\begin{aligned}
& \frac{d}{d t}\left\{\left(\frac{3}{2} m+M\right) \dot{p}+M l \dot{\theta} \cos \theta\right\}-0=f \\
& \left(\frac{3}{2} m+M\right) \ddot{p}+M l \ddot{\theta} \cos \theta-M l \dot{\theta}^{2} \sin \theta=f
\end{aligned}
$$

Untuk menyelesaikan $\theta$ dengan persamaan Lagrange dijelaskan pada pada Persamaan (12).

$$
\frac{d}{d t}\left(\frac{\partial L}{\partial \dot{\theta}}\right)-\frac{\partial L}{\partial \theta}=0
$$


Robot Inverted Pendulum Beroda Dua (IPBD) dengan Kendali Linear Quadratic Regulator(LQR)

Menggunakan Persamaan (9) untuk mengevaluasi turunan parsial pada Persamaan (12) maka dihasilkan Persamaan (13).

$$
\begin{aligned}
& \frac{d}{d t}\left(M l \dot{p} \cos \theta+M l^{2} \dot{\theta}\right)-M g l \sin \theta=0 \\
& M l \ddot{p} \cos \theta-M l \dot{p} \sin \theta+M l^{2} \ddot{\theta}-M g l \sin \theta=0
\end{aligned}
$$

Sehingga persamaan sistem untuk robot IPBD dapat disajikan pada Persamaan (14).

$$
\begin{aligned}
& \left(\frac{3}{2} m+M\right) \ddot{p}+M l \ddot{\theta} \cos \theta-M l \dot{\theta}^{2} \sin \theta=f \\
& M l \ddot{p} \cos \theta-M l \dot{p} \sin \theta+M l^{2} \ddot{\theta}-M g l \sin \theta=0
\end{aligned}
$$

5. Linearisasi

Persamaan (14) tersebut adalah non-linear. Karena tujuan sistem kendali adalah menjaga bandul tetap tegak, persamaan tersebut dapat di-linear-kan yang berlaku untuk $\sin \theta \approx 0$ dan $\cos \theta \approx 1$ sehingga menjadi Persamaan (15).

$$
\begin{aligned}
& \left(\frac{3}{2} m+M\right) \ddot{p}+M l \ddot{\theta}=f \\
& M \ddot{p}+M l \ddot{\theta}-M g \theta=0
\end{aligned}
$$

Dengan menyelesaikan Persamaan (15) akan didapat $\ddot{p}$ dan $\ddot{\theta}$ yang disajikan pada Persamaan (16).

$$
\begin{aligned}
& \ddot{p}=\frac{2 f}{3 m}-\frac{2 M g}{3 m} \theta \\
& \ddot{\theta}=-\frac{2 f}{3 m l}+\left(\frac{3 m+2 M}{3 m l}\right) g \theta
\end{aligned}
$$

Bila pada Persamaan (16) disajikan dalam bentuk state space maka diperoleh Persamaan (17). Dimana $u$ adalah gaya yang bekerja pada sistem robot IPBD , $f$.

$$
\begin{aligned}
& \dot{x}=A x+B u \\
& \dot{x}=\left[\begin{array}{cccc}
0 & 1 & 0 & 0 \\
\left(\frac{3 m+2 M}{3 m l}\right) g & 0 & 0 & 0 \\
0 & 0 & 0 & 1 \\
-\frac{2 M}{3 m} g & 0 & 0 & 0
\end{array}\right]\left[\begin{array}{c}
\theta \\
\dot{\theta} \\
p \\
\dot{p}
\end{array}\right]+\left[\begin{array}{c}
0 \\
-\frac{2}{3 m l} \\
0 \\
\frac{2}{3 m}
\end{array}\right] u
\end{aligned}
$$

\subsection{Linear Quadratic Regulator (LQR)}

Selain metode pole placement (Tewari, 2002), kendali keseimbangan juga dapat dirancang dengan menggunakan LQR. LQR adalah sebuah kendali optimal yang bertujuan membawa state akhir ke titik nol dengan meminimalkan cost function. Jenis kendali ini bertujuan mencari nilai gain state feedback (K) (Zhou, 1996). Misalkan sebuah plant mempunyai bentuk state space pada Persamaan (18).

$$
\begin{gathered}
\dot{x}=A x+B u \\
y=C x
\end{gathered}
$$

dengan indeks performansi pada Persamaan (19).

$$
J=\frac{1}{2} \int_{t_{0}}^{T}\left\{x^{T}(t) Q x(t)+u^{T}(t) R u(t)\right\} d t
$$

Dimana $\mathrm{Q}$ adalah matriks positive-definite, positive-semidefinite, atau real simetris dan $\mathrm{R}$ adalah matriks positive-definite atau real simetris. Matrik $\mathrm{x}^{*}$ dan $\mathrm{u}^{*}$ merupakan conjugate transpose dari matriks $\mathrm{x}$ dan $\mathrm{u}$. Conjugate transpose (sering juga disebut adjoint matriks 
atau hermitian transpose) dari suatu matriks diperoleh dengan mencari transpose Matrix lalu conjugate complex dari tiap elemen matriks tersebut dicari. Perlu diperhatikan bahwa bagian kedua disebelah kanan pada persamaan menunjukan perhitungan energi dari sinyal kendali yang dikeluarkan. Pembobotan matriks $\mathrm{Q}$ dan $\mathrm{R}$ menentukan kepentingan relatif dari kesalahan dan pengeluaran energi ini. Dalam hal ini, diasumsikan bahwa vector kendali $u(t)$ tidak terkendali. Jika diperoleh elemen matriks $\mathrm{K}$ yang dapat memenimalkan indeks perfoma, maka $\mathrm{u}(\mathrm{t})=-\mathrm{Kx}(\mathrm{t})$ akan optimal untuk setiap initial state $\mathrm{x}(0)$. Diagram blok untuk konfigurasi LQR ditunjukkan oleh Gambar 2.

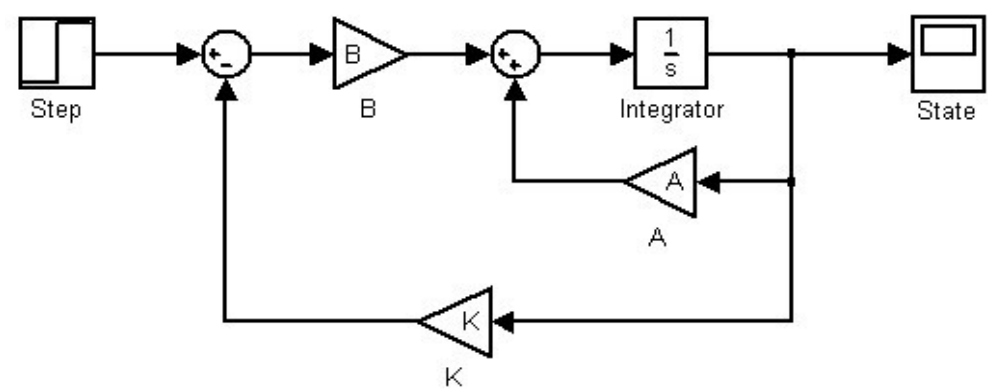

Gambar 2. Diagram Blok LQR

Mencari nilai gain state feedback (K) pada Matlab bisa dilakukan dengan sintaks: " $[\mathrm{K}, \mathrm{S}, \mathrm{E}]=\operatorname{lqr}(\mathrm{A}, \mathrm{B}, \mathrm{Q}, \mathrm{R})$ ", dengan $\mathrm{S}$ adalah solusi persamaan Riccati dan $\mathrm{E}$ adalah closed-loop eigenvalue. Persoalan regulator dapat diselesaikan dengan menyelesaikan persamaan Riccati pada Persamaan (20).

$$
A^{T} P+P A-P B R^{-1} B^{T} P+Q=0
$$

Pemilihan pembobot matriks $\mathrm{Q}$ dan $\mathrm{R}$ berpedoman pada: semakin besar harga matriks $\mathrm{Q}$, semakin besar harga elemen penguatan $\mathrm{K}$ sehingga mempercepat sistem untuk mencapai keadaan tunak (intermediate state cost function). Bila nilai $\mathrm{R}$ diperbesar, maka nilai penguatan $\mathrm{K}$ akan mengecil dan keadaan tunak/steady (energy drive) melambat.

\section{SIMULASI}

Model dari robot IPBD dibangun dengan menggunakan Simulink. Pada model ini, masukan dari model adalah aksi pengendali. Variabel sudut dari iterasi sebelumnya digunakan untuk menghitung percepatan robot dan percepatan sudut dari bandul menggunakan Persamaan (16) dan Persamaan (17) secara berurutan. Integrasi kemudian dilakukan untuk mendapatkan kecepatan dan posisi untuk kedua komponen yang bersangkutan. Sudut dan kecepatan sudut dari bandul serta posisi dan kecepatan sudut dari robot adalah keluaran dari model ini. Berdasarkan Persamaan (17) pemodelan dalam Simulink disajikan pada Gambar 3 dengan menggunakan data parameter dari robot IPBD yang disajikan pada Tabel 1.

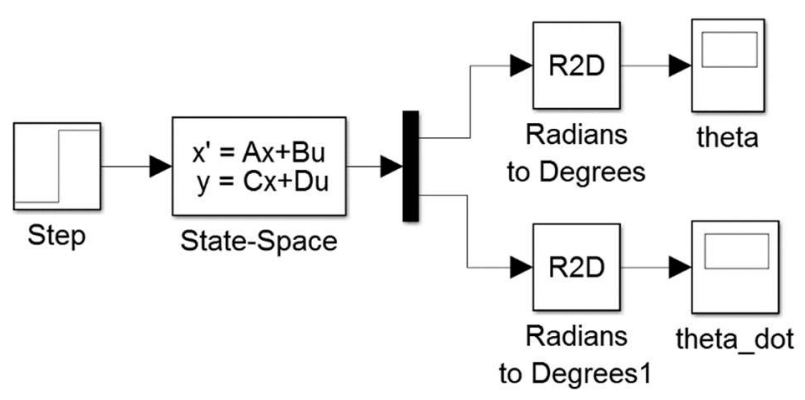

Gambar 3. Model Simulink untuk Sistem Robot IPBD (Open Loop) 
Tabel 1. Paramerter dari Robot IPBD

\begin{tabular}{|c|l|c|l|}
\hline Parameter & \multicolumn{1}{|c|}{ Deskripsi } & Nilai & Satuan \\
\hline$m$ & Massa dari roda & 0.05 & $\mathrm{~kg}$ \\
\hline$M$ & Massa dari pendulum & 0.3 & $\mathrm{~kg}$ \\
\hline$l$ & Panjang pendulum & 0.17 & meter \\
\hline$g$ & $\begin{array}{l}\text { Percepatan gravitasi } \\
\text { bumi }\end{array}$ & 9.81 & $\mathrm{~m} / \mathrm{s}^{\wedge} 2$ \\
\hline
\end{tabular}

Respon open loop untuk sistem ini didapat dengan menggunakan model Simulink dan model state space pada Persamaan (17). Hasil respon open loop disajikan pada Gambar 4 dengan hasil bahwa sistem adalah tidak stabil, karena robot IPBD cepat sekali jatuh menuju horizontal dari posisi tegak vertikalnya. Hal ini juga dapat dilihat pada Tabel 2 untuk posisi pole yang dapat dicari dari eigen value matriks A pada persamaan state space serta memeriksa rank matriks controllability dan observability.

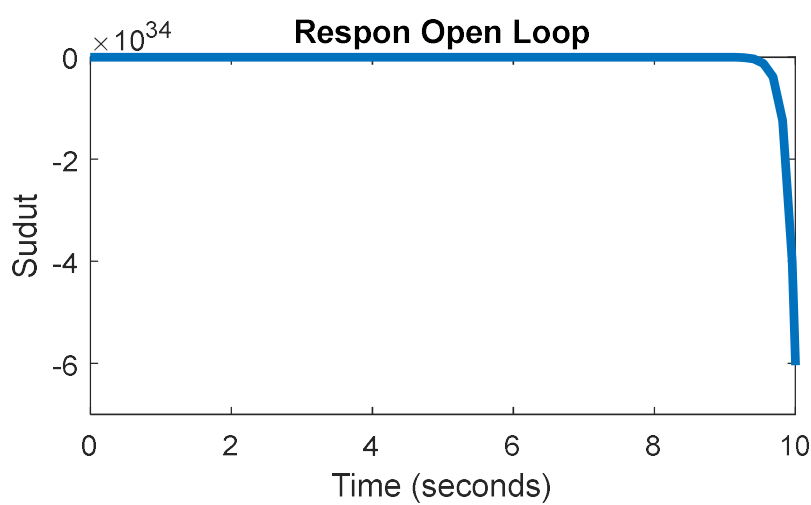

Gambar 4. Respon Open Loop dari Model Robot IPBD

Pada Tabel 2 dapat dilihat bahwa terdapat sebuah pole di bidang sebelah kanan yaitu pada +16.97, yang menandakan sistem open loop ini tidak stabil. Oleh karena itu, untuk memindahkan semua pole ke bidang kiri dan untuk mempertahankan posisi bandul agar tetap tegak dibutuhkan suatu pengendali. Respon close loop untuk sistem ini didapatkan dengan menambahkan suatu pengendali pada sistem open loop-nya. Dengan menambahkan gain matriks $\mathrm{K}$ yang dicari dengan teknik LQR sebagai umpan balik sistem seperti pada Gambar 5, nilai gain matriks K dapat dihitung dengan bantuan Matlab, seperti yang disajikan pada Tabel 3.

Hasil eksekusi program pada Tabel 3, menunjukkan bahwa matriks $\mathrm{P}$ merupakan matriks positive-definite dan dapat dicari, maka sistem closed loop ini stabil, selain itu dapat dilihat juga bahwa semua pole dapat dipindahkan kebidang kiri, seperti yang ditunjukan pada matriks E. Selanjutnya, respon close loop dapat dilihat pada Gambar 6. Hasil dari umpan balik gain $\mathrm{K}$ menyebabkan nilai sudut bandul robot IPBD dapat menuju nol. Penambahan pengendali menyebabkan sistem robot IPBD menjadi stabil. Pada hasil simulasi nilai sudut, akan mengalami osilasi pada awalnya, karena kondisi awal sebelum sistem dijalankan nilai sudut kemiringan robot IPBD tidak tepat berada pada nol derajat. Kemudian sistem akan menuju stabil menuju nilai nol (posisi tegak vertikal). 
Tabel 2. Model IPBD, Pole, Controllability dan Observability

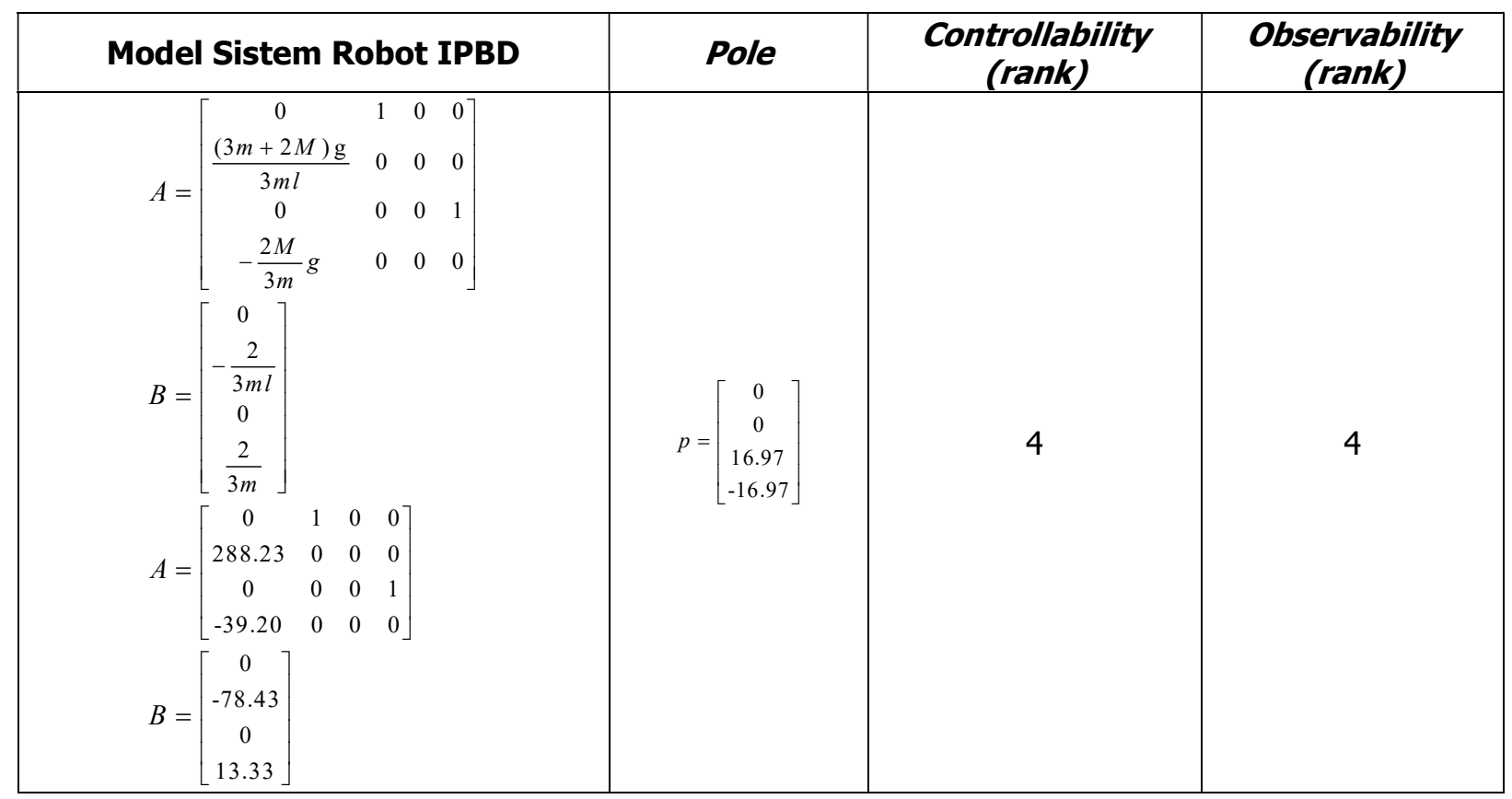

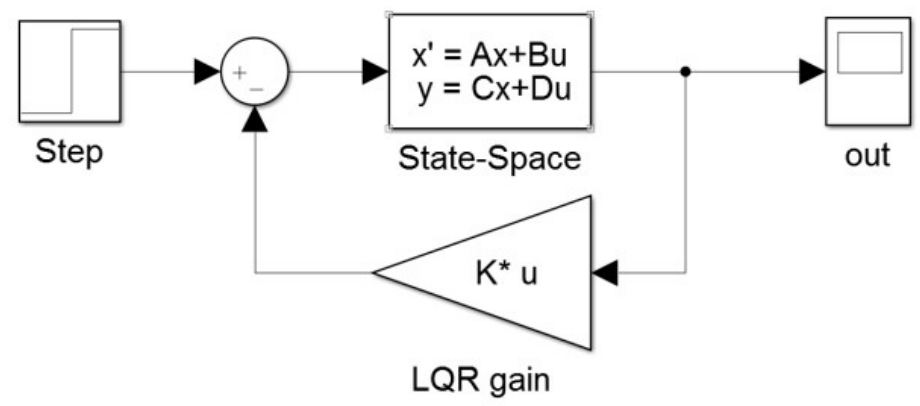

Gambar 5. Simulink Model Inverted Pendu/um dengan Gain Feedback K yang Diperoleh dari LQR

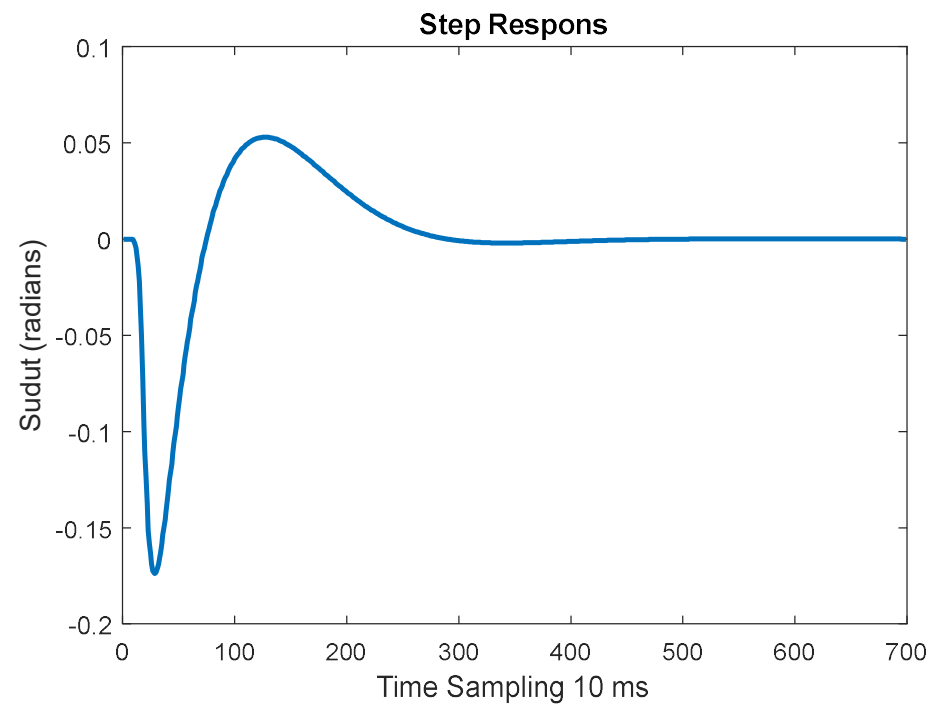

Gambar 6. Respon Close Loop dari Model Robot IPBD menggunakan LQR 
Tabel 3. Pemrograman pada Matlab untuk Mencari Gain K Menggunakan LQR

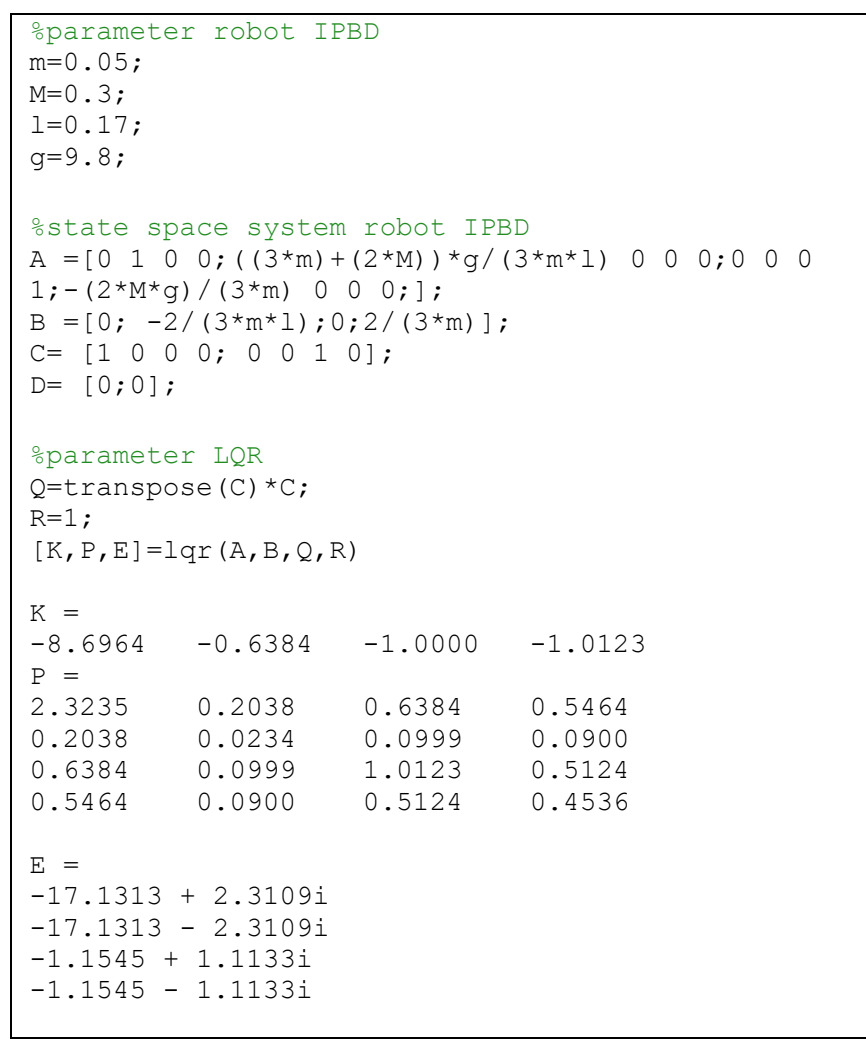

Untuk tahap paling awal, tuning matriks pembobot $\mathrm{Q}$ dan $\mathrm{R}$ dilakukan dengan memberikan nilai pembobot $\mathrm{R}=1$ dan matriks $Q=C^{T} * C$, namun semakin besar bobot matriks $\mathrm{Q}$ akan mempercepat respon menuju keadaan steady. Dengan mengubah-ubah matriks pembobot $\mathrm{Q}$ akan diperoleh variasi gain $\mathrm{K}$. Berikut nilai variasi pembobotan matriks $\mathrm{Q}$ yang dilakukan pada penelitian ini sebanyak lima variasi seperti yang disajikan pada Tabel 4. Gambar 7 menyajikan perbedaan respons closed loop sistem dengan variasi pembobotan matriks Q. Grafik respon pada Gambar 7 menunjukkan bahwa parameter pembobotan matriks Q ke-5 menghasilkan rise time (tr) yang paling cepat dibandingan dengan yang lain dan paling kecil mengalami overshoot.

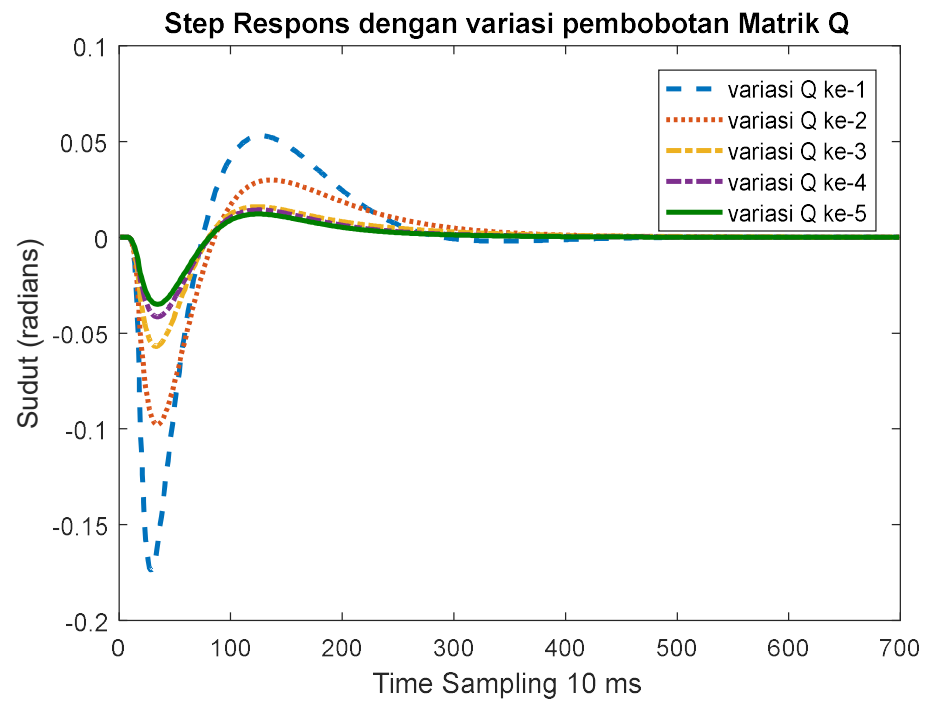

Gambar 7. Grafik Step Respons dengan Variasi Pembobotan Matriks $\mathbf{Q}$ 
Tabel 4. Paramerter Matriks Q dan Hasil Gain $\mathrm{K}$

\begin{tabular}{|c|c|c|}
\hline No. & Parameter matriks pembobot Q & Gain K dengan LQR \\
\hline 1. & $Q=C^{T} * C$ & $K=\left[\begin{array}{c}-8.6964 \\
-0.6384 \\
-1 \\
-1.0123\end{array}\right]$ \\
\hline \multirow{2}{*}{. } & $Q=\left[\begin{array}{llll}1 & 0 & 0 & 0 \\
0 & 1 & 0 & 0 \\
0 & 0 & 1 & 0 \\
0 & 0 & 0 & 1\end{array}\right]$ & $K=\left[\begin{array}{c}-11.1413 \\
-1.4140 \\
-1 \\
-1.5886\end{array}\right]$ \\
\hline \multirow{3}{*}{3.} & $Q=\left[\begin{array}{llll}3 & 0 & 0 & 0 \\
0 & 3 & 0 & 0 \\
0 & 0 & 3 & 0 \\
0 & 0 & 0 & 3\end{array}\right]$ & $K=\left[\begin{array}{l}-16.0448 \\
-2.4036 \\
-1.7321 \\
-3.0615\end{array}\right]$ \\
\hline 4. & $Q=\left[\begin{array}{cccc}7 & 0 & 0 & 0 \\
0 & 7 & 0 & 0 \\
0 & 0 & 7 & 0 \\
0 & 0 & 0 & 7\end{array}\right]$ & $K=\left[\begin{array}{l}-20.2733 \\
-3.4555 \\
-2.6458 \\
-3.9953\end{array}\right]$ \\
\hline 5. & $Q=\left[\begin{array}{cccc}10 & 0 & 0 & 0 \\
0 & 10 & 0 & 0 \\
0 & 0 & 10 & 0 \\
0 & 0 & 0 & 10\end{array}\right]$ & $K=\left[\begin{array}{l}-23.2890 \\
-4.1061 \\
-3.1623 \\
-4.7601\end{array}\right]$ \\
\hline
\end{tabular}

\section{IMPLEMENTASI}

\subsection{Perancangan Mekanik dan Elektronik}

Rancangan mekanik robot IPBD menggunakan dua buah roda dan desain mekanik robot ini diusahakan dapat seimbang pada titik pusat massa robot. Desain mekanik dan bentuk real fisik dari robot IPBD diperlihatkan pada Gambar 8.

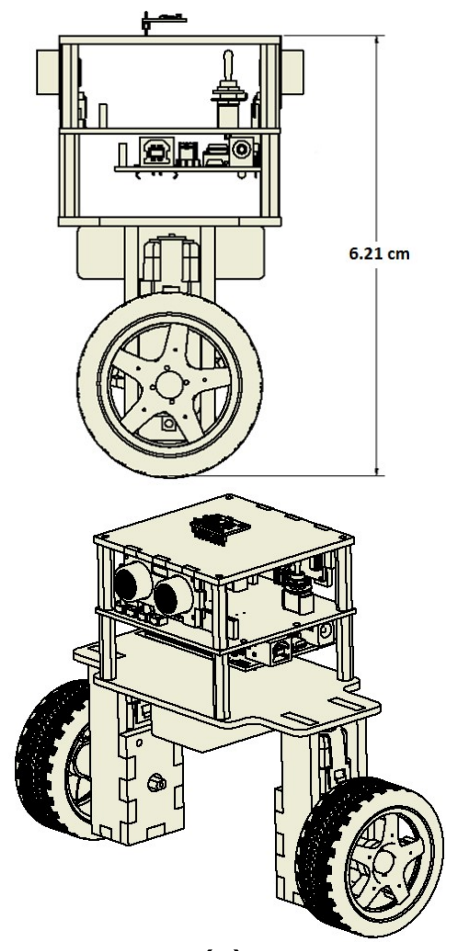

(a)

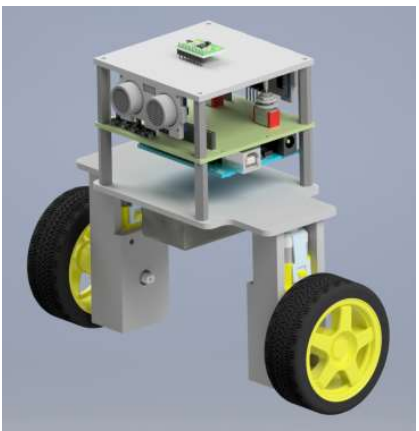

(b)

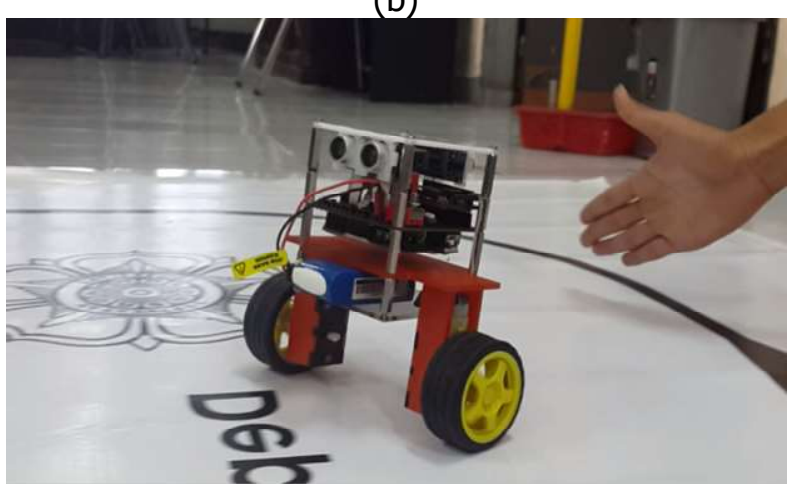

(c)

Gambar 8. (a)-(b) Desain CAD Robot IPBD. (c) Hasil Desain Robot IPBD 
Sistem elektronik robot IPBD menggunakan Arduino Uno sebagai kendali utamanya. Adapun konfigurasi diagram blok sistem elektronika dari robot dijelaskan pada Gambar 9.

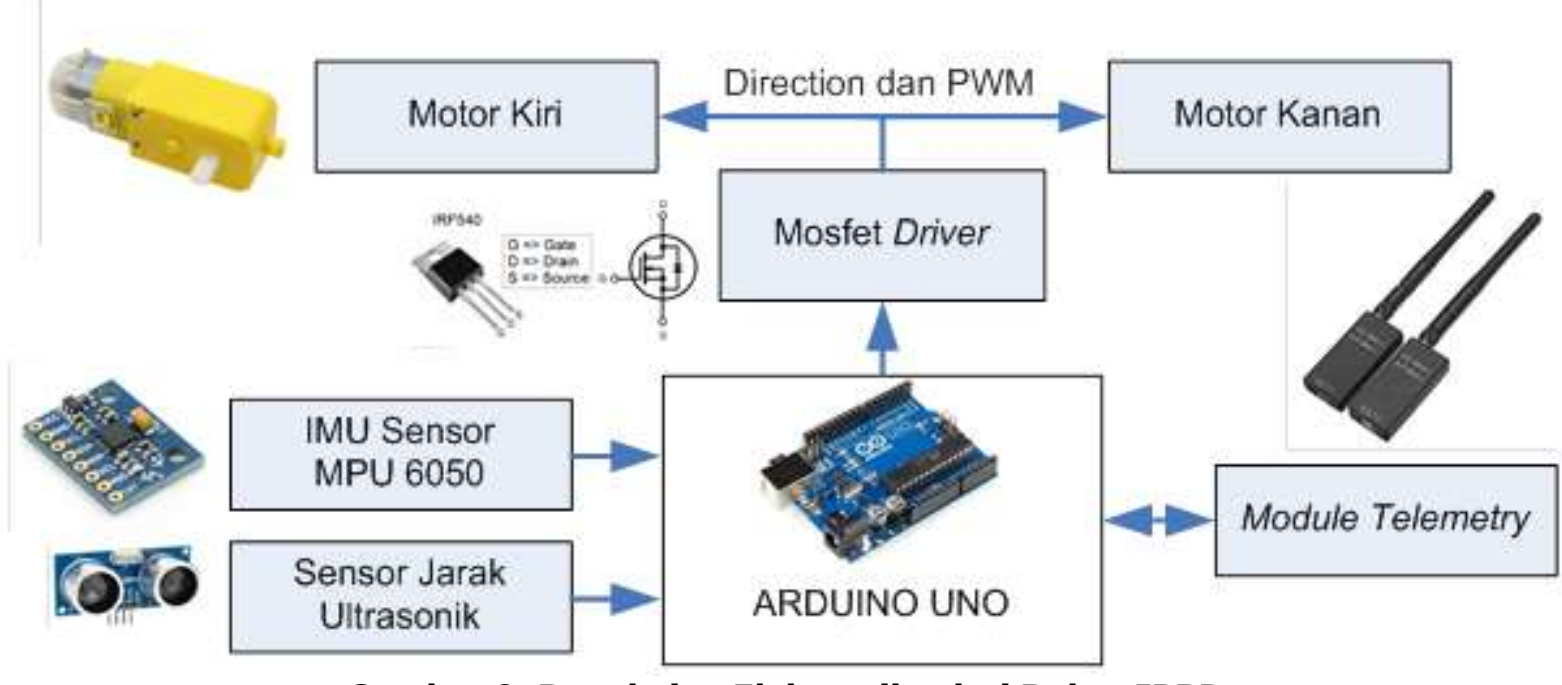

Gambar 9. Rangkaian Elektronika dari Robot IPBD

Data kemiringan dari robot ini menggunakan sebuah perangkat sensor IMU. Perangkat ini mampu mengukur dan melaporkan kecepatan, orientasi, dan gaya gravitasi. Pada penelitian ini, robot IPBD menggunakan sensor IMU MPU 6050. Sensor ini memiliki konfigurasi sebagai berikut: memilik 6 derajat kebebasan, terdiri atas dua konfigurasi accelerometer dan gyroscope dengan komunikasi protokol data menggunakan Inter Ingrated Circuit(I2C).

Dalam proses suatu pengukuran dengan IMU sensor, noise merupakan gangguan penting yang harus diperhatikan dan ditapis. Oleh karena itu, untuk mendapatkan sinyal sebenarnya yang terpisah dari sekumpulan noise, teknik penyaringan (filtering) sangat dibutuhkan. Pada penelitian ini, complementary filter (CF) digunakan untuk menghilangkan noise. Konfigurasi dari CF untuk sudut theta pada sumbu axis-y pada pergerakan pitch dijelaskan pada Gambar 10.

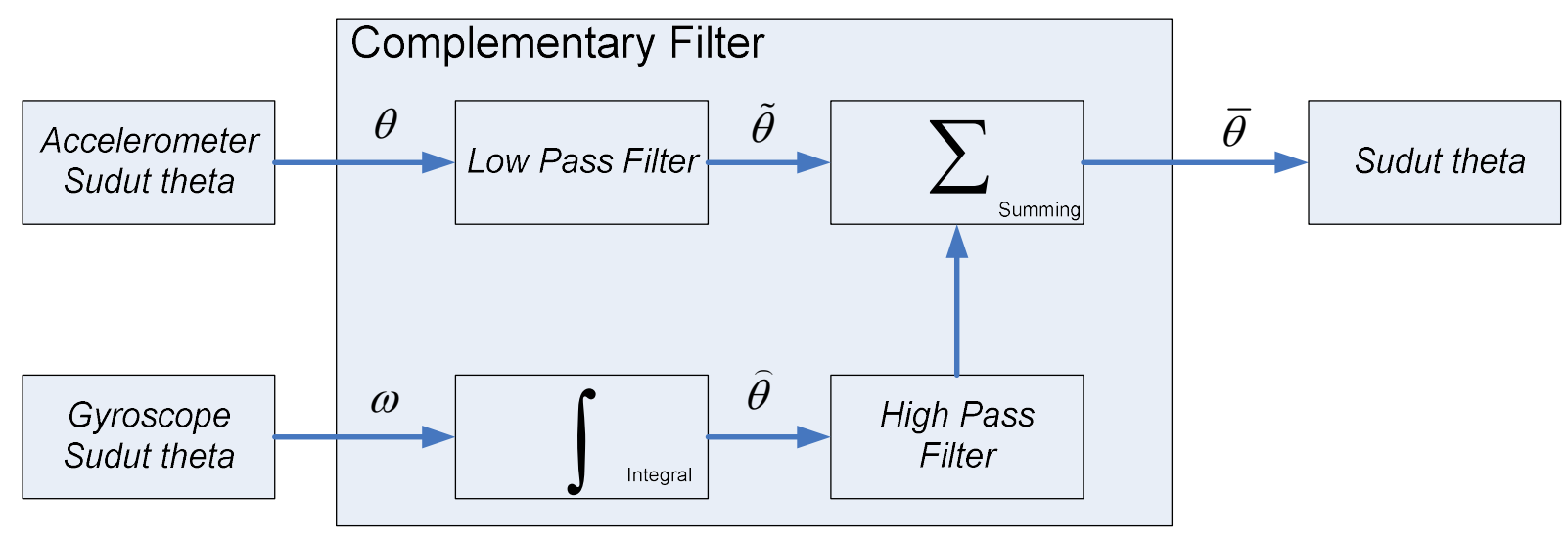

Gambar 10. Blok Diagram Complementary Filter

\subsection{Perancangan Perangkat Lunak LQR}

Rancangan perangkat lunak untuk sistem robot IPBD berisi tentang pembacaaan sensor kemiringan oleh IMU sensor dan sensor posisi dengan menggunakan sensor ultrasonik. Datadata sensor tersebut dijadikan sebagai masukan untuk diolah dengan menggunakan LQR. 
Matriks gain $\mathrm{K}$ sebagai umpan balik telah diperoleh dari hasil pemodelan sistem IPBD pada Persamaan (17). Berikut ini diagram alir penerapan kendali LQR pada sistem robot IPBD secara keseluruhan yang disajikan pada Gambar 11.

Parameter gain $\mathrm{K}$ dari hasil simulasi akan diimplementasikan secara embedded programming kedalam Arduino Uno pada sistem robot IPBD. Selain itu, untuk memudahkan proses pengamatan respons sistem robot IPBD, telah dikembangkan Graphical User Interface (GUI) dengan Processing IDE seperti yang disajikan pada Gambar 12. GUI ini memberikan informasi kondisi kemiringan robot IPBD pada sumbu axis-y pada pergerakan pitch.

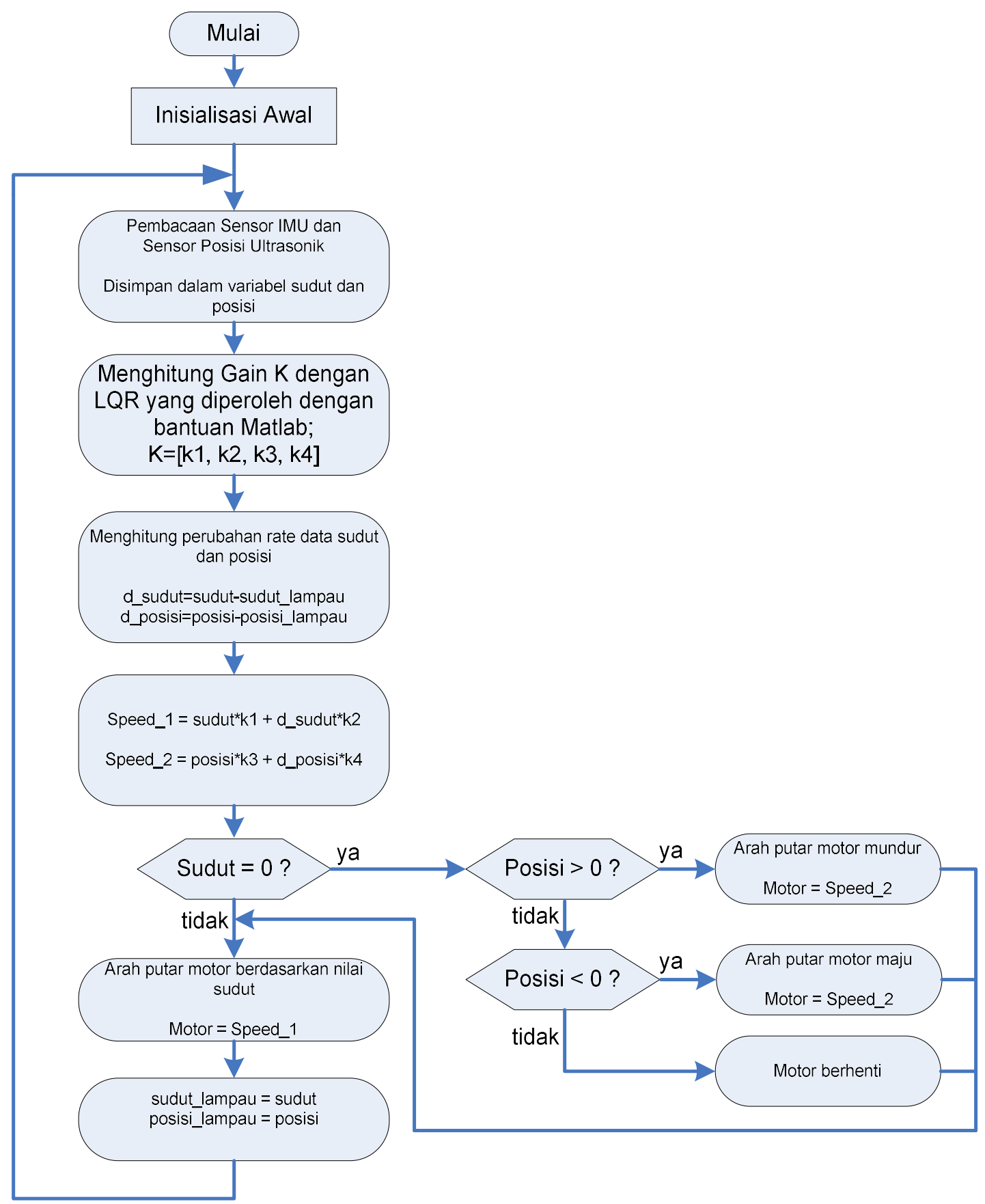

Gambar 11. Diagram Alir Penerapan Kendali LQR pada Sistem Robot IPBD 


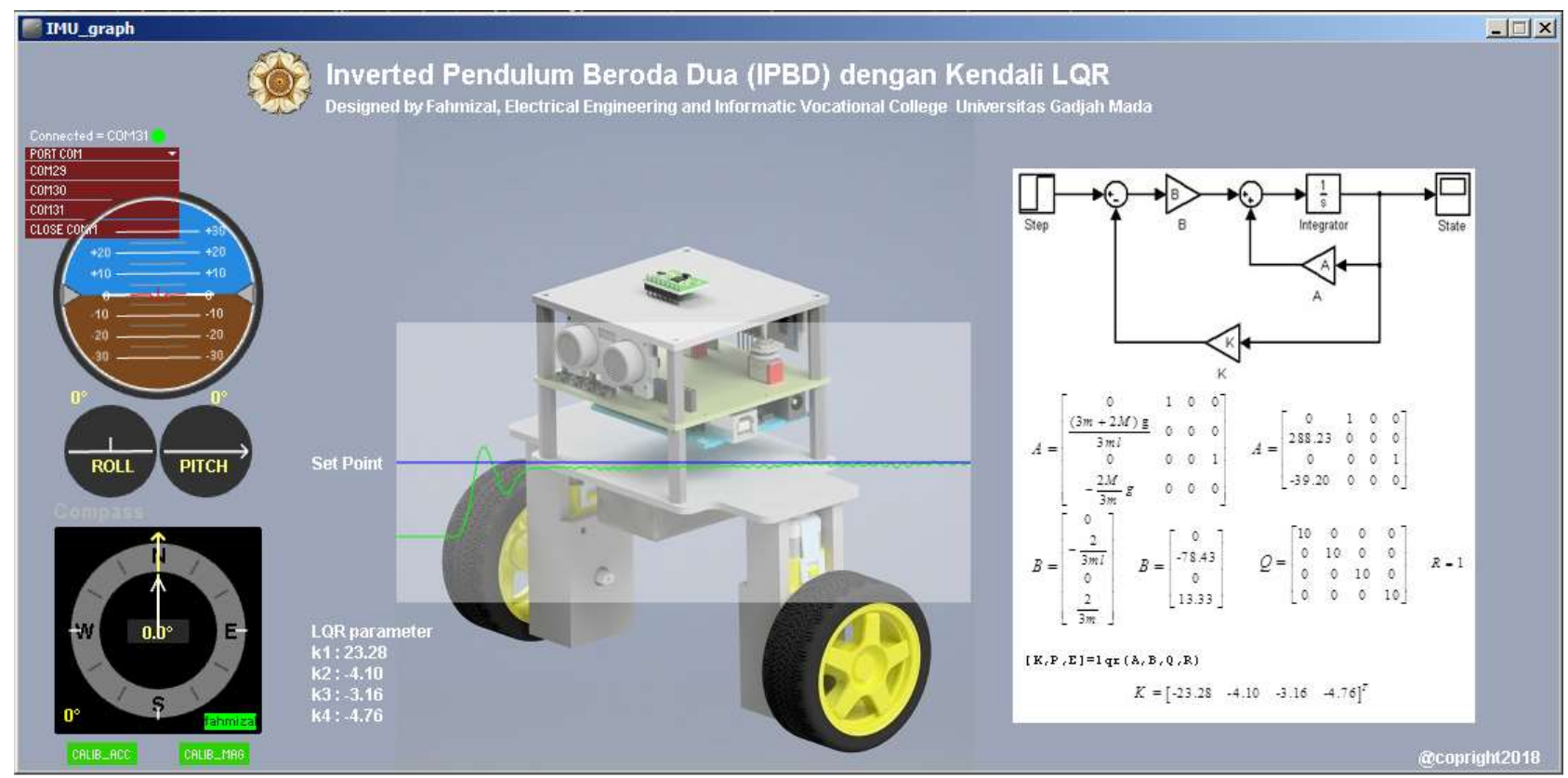

\section{Gambar 12. Rancangan GUI Robot IPBD}

\section{KESIMPULAN}

Dari hasil pengamatan, pengujian dan analisis, maka dapat ditarik beberapa simpulan. Perangkat keras sistem robot IPBD telah berhasil dibangun dengan baik memanfaatkan dua roda dan dua Motor DC menggunakan Arduino Uno sebagai embeded system-nya. Sensor IMU MPU6050 dan sensor jarak digunakan sebagai kondisi masukan state berupa sensor sudut kemiringan dan sensor posisi. Kendali LQR digunakan untuk menentukan nilai gain $\mathrm{K}$ dalam sistem closed loop dengan mempertimbangkan energi yang optimal yang digunakan untuk memindah pole pada bidang sebelah kanan (daerah tidak stabil) menuju bidang sebelah kiri (daerah stabil). Dari hasil pengujian diperoleh bahwa dengan membesarkan pembobotan matriks $\mathrm{Q}$ menghasilkan respon menuju keadaan steady lebih cepat dan mengurangi overshoot. Langkah lanjutan pada penelitian ini ialah menambahkan kendali cerdas buatan seperti algoritma genetika yang dapat digunakan untuk men-tuning parameter matriks Q.

\section{UCAPAN TERIMA KASIH}

Penulis mengucapkan terima kasih kepada Departemen Teknik Elektro dan Informatika Sekolah Vokasi Universitas Gadjah Mada atas dukungan yang telah diberikan kepada penulis.

\section{DAFTAR RUJUKAN}

Fasola, J., \& Matarić, M. J. (2013). A socially assistive robot exercise coach for the elderly. Journal of Human-Robot Interaction, 2(2), 3-32.

Song, G., Yin, K., Zhou, Y., \& Cheng, X. (2009). A surveillance robot with hopping capabilities for home security. IEEE Transactions on Consumer Electronics, 55(4). 
Nagatani, K., Kiribayashi, S., Okada, Y., Tadokoro, S., Nishimura, T., Yoshida, T., ... \& Hada, Y. (2011, November). Redesign of rescue mobile robot Quince. In Safety, Security, and Rescue Robotics (SSRR), 2011 IEEE International Symposium on (pp. 13-18). IEEE.

Kim, K., Bae, S., \& Huh, K. (2010, October). Intelligent surveillance and security robot systems. In 2010 IEEE Workshop on Advanced Robotics and its Social Impacts (pp. 70-73). IEEE.

Zhang, H., Zhang, J., Zong, G., Wang, W., \& Liu, R. (2006). Sky cleaner 3: A real pneumatic climbing robot for glass-wall cleaning. IEEE Robotics \& Automation Magazine, 13(1), $32-41$.

Kuo, C. H., Zal, F., \& Wu, S. L. (2016). Development of Fuzzy Logic Controllers for Controlling Bipedal Robot Locomotion on Uneven Terrains with IMU Feedbacks. Indian Journal of Science and Technology, 9(28).

Mayub, A., \& Fahmizal, F. (2018). Center of Pressure Feedback for Controlling the Walking Stability Bipedal Robots using Fuzzy Logic Controller. International Journal of Electrical and Computer Engineering (IJECE), 8(6).

Pratama, D., Binugroho, E. H., \& Ardilla, F. (2015, September). Movement control of two wheels balancing robot using cascaded PID controller. In Electronics Symposium (IES), 2015 International (pp. 94-99). IEEE.

Bobby, G., Susanto, E., \& Suratman, F. Y. (2015). Implementasi Robot Keseimbangan Beroda Dua Berbasis Mikrokontroler. ELKOMIKA: Jurnal Teknik Energi Elektrik, Teknik Telekomunikasi, \& Teknik Elektronika, 3(2), 142.

Fahmizal, F., Arrofiq, M., \& Mayub, A. (2017). Logika Fuzzy pada Robot Inverted Pendulum Beroda Dua. Jurnal Teknologi Informasi dan IImu Komputer, 4(4), 244-252.

Huang, J., Guan, Z. H., Matsuno, T., Fukuda, T., \& Sekiyama, K. (2010). Sliding-mode velocity control of mobile-wheeled inverted-pendulum systems. IEEE Transactions on robotics, 26(4), 750-758.

Tewari, A. (2002). Modern control design. NY: John Wiley \& sons, 283-308.

Zhou, K., Doyle, J. C., \& Glover, K. (1996). Robust and optimal control(Vol. 40, p. 146). New Jersey: Prentice hall. 